\title{
BIG DATA TECHNOLOGY APPLICATIONS IN AGRICULTURE: A SYSTEMATIC LITERATURE REVIEW
}

\section{APLICAÇÕES DA TECNOLOGIA DE BIG DATA NA AGRICULTURA: UMA REVISÃO SISTEMÁTICA DA LITERATURA}

Recebido em: 26 jul. 2020

Aprovado em: 18 out. 2020

Versão do autor aceita publicada online: 18 out. 2020

Publicado online: 25 jun. 2021

\section{Como citar esse artigo - American Psychological Association (APA):}

Tamachiro, T. S. O., Oliveira, F. R., Gayer, J. A. C. A., Kleina, M., \& Marques, M. A. M. (2022, abr./jun.). Big data technology applications in agriculture: a systematic literature review. Exacta. 20(2), 388-402. https://doi.org/10.5585/exactaep.2021.17765.

Submeta seu artigo para este periódico $\beta$

Dados Crossmark 


\title{
BIG DATA TECHNOLOGY APPLICATIONS IN AGRICULTURE: A SYSTEMATIC LITERATURE REVIEW
}

\author{
APLICAÇÕES DA TECNOLOGIA DE BIG DATA NA AGRICULTURA: UMA REVISÃO \\ SISTEMÁTICA DA LITERATURA
}

\author{
iD Thiago Shoji Obi Tamachiro ${ }^{1}$ \\ (iD) Fernanda Robes de Oliveira ${ }^{2}$ \\ iD Jéssika Alvares Coppi Arruda Gayer ${ }^{3}$ \\ iD Mariana Kleina ${ }^{4}$ \\ iD Marcos Augusto Mendes Marques ${ }^{5}$
}

\begin{abstract}
${ }^{1}$ Mestre em Engenharia de Produção Universidade Federal do Paraná - UFPR. Curitiba, Paraná - Brasil. thiagotamachiro@gmail.com
\end{abstract}

${ }^{2}$ Mestre em Engenharia de Produção Universidade Federal do Paraná - UFPR. Curitiba, Paraná - Brasil.

fer.robes@gmail.com

${ }^{3}$ Mestre em Engenharia de Produção Universidade Federal do Paraná - UFPR. Curitiba, Paraná - Brasil. jessika.ac@hotmail.com

${ }^{4}$ Doutora em Métodos Numéricos em Engenharia Universidade Federal do Paraná - UFPR.

Curitiba, Paraná - Brasil.

marianakleina@ufpr.br

${ }^{5}$ Doutor em Métodos Numéricos em Engenharia Universidade Federal do Paraná - UFPR. Curitiba, Paraná - Brasil. marquesammarcos@gmail.com

Recebido em: 26 jul. 2020

Aprovado em: 18 out. 2020
Abstract: Industry 4.0 is a terminology widely used today. Among the technologies that make up this new trend, there is Big Data, which is a broad set of data with a large number of variables, high number and high speed. The objective of this article was to carry out a systematic review of the literature regarding the current issues that address the use of Big Data in the context of Agriculture. The systematic literature review was able to verify how this sector analyzes and processes the large volume of data generated. Thus, there was a search for articles published on the Web of Science and Scopus in the intervals between 2016 and 2019, which contained as Big Data and agriculture. The material found was analyzed, compiled and presented in the form of a table with a short summary on what to approach the articles. As a result, it was observed that a large part of the studies refer to the use of analysis and machine learning techniques of data sets from Big Data, which propose solutions to problems arising from agriculture. In addition, this study serves as a reference on the Big Data techniques most used in agriculture aiming at increasing productivity and better decision making.

Keywords: Big Data. Agriculture. Industry 4.0.

Resumo: A indústria 4.0 é uma terminologia muito utilizada nos dias atuais. Dentre as tecnologias que compõem esta nova tendência, tem-se o Big Data, que é um amplo conjunto de dados com um grande número de variáveis, num alto volume e em alta velocidade. O objetivo deste artigo foi realizar uma revisão sistemática da literatura referente aos assuntos atuais que abordam a utilização de Big Data no contexto da Agricultura. A revisão sistemática da literatura teve por finalidade verificar como este setor analisa e processa o grande volume de dados gerados. Desta forma, houve uma busca por artigos publicados na base Web of Science e Scopus nos períodos entre 2016 a 2019 que continham as palavras Big Data e agricultura. O material encontrado foi analisado, compilado e apresentado em forma de quadro com um pequeno resumo sobre o que abordam os artigos. Como resultado, observou que grande parte dos estudos referem à utilização de técnicas de análise e aprendizado de máquina dos conjuntos de dados provenientes do Big Data, em que propõem soluções aos problemas decorrentes da agricultura. Além disso, este estudo serve como um referencial sobre as técnicas de Big Data mais utilizadas na Agricultura visando o aumento da produtividade e melhores tomadas de decisão.

Palavras-chave: Big Data. Agricultura. Indústria 4.0. 


\section{Introduction}

Industry 4.0, a term raised by the German Government in 2011, has as main focus to apply advanced technologies at the production level, aiming at increasing the flexibility, speed and quality of production systems (Khan \& Turowski, 2016). These advanced technologies, such as, additive manufacturing, Internet of Things (IOT), Big Data and cloud computing, if integrated, will bring about major changes in the way society organizes, relates, consumes and produces products and services (Manyika et al., 2013).

The term Big Data can be defined as the existence of large data sets and that need adequate tools to deal with this large volume of data and from this medium, information can be extracted for decision making (Morais et al., 2018 ).

According to Shivappa et al. (2018) Big Data has three main characteristics or dimensions, described as: the volume defined as a set of data whose size is beyond the processing capacity of a conventional database; the speed that is the ability to acquire, process, understand and interpret data in real time; and the variety in which it refers to the number of data types, such as messages, photos, videos and sounds. Morais et al. (2018) still include two more dimensions: veracity (constant need for real-time analysis) and value (indicates that the greater the wealth of data, the better the questions will be at the beginning of the analysis process).

Faced with this technological revolution, which appears to be applied with greater proportion in the manufacturing industry, Agriculture 4.0 (including precision agriculture and agriculture) is also present, which uses techniques from industry 4.0 to maximize the use of natural resources for food production (Ribeiro et al., 2012). Big data and cloud computing techniques have been widely used in agriculture 4.0, with the objective of providing better decision-making for increasing productivity (Franco \& Domenech, 2014).

According to the Agricultural Census, carried out in 2017 and published in 2019, by the Instituto Brasileiro de Geografia e Estatística (IBGE), internet access by Brazilian agricultural establishments jumped from 75 thousand in 2006, to $1,430,156$ in 2017, that is, an increase of more than $1900 \%$ or almost 20 times more. In addition, the evolution is marked by 659 thousand accesses by broadband and 909 thousand accesses by mobile internet.

With that, the hypothesis was raised that there is a large volume of information in agriculture that needs to be treated, in order to improve the forecasts in the segment, however it is unknown which tools help in this tabulation.

From the understanding of the concept of Big Data, the question that motivated this research arose, described as: "Currently, what are the innovations and technologies, connected to Big Data, used in agriculture?". 
The study is justified from the need to understand how Big Data can be used outside the industrial context, and yes, in other segments in order to understand the customer's needs, in addition to improving production processes. Another point, which is necessary to understand, is whether this technological advent with high data processing, Big Data, is at what level within agriculture and in which approach has been applied. Therefore, the objective of this study is to carry out a systematic review of the literature regarding current issues that address the use of Big Data in the context of Agriculture.

For this, the article is divided into 4 sections, the first of which brings an introduction on the topic; the second addresses the research methodology; in the third are the results and discussion on the topic; and the fourth section presents the final considerations.

\section{Research methodology}

The proposed research has a qualitative nature and relates the uses and problems of Big Data in the area of Agriculture, using the method described by Tranfield et al. (2003). This method suggests three main steps, namely: research planning, with the definition of parameters; searching and extracting articles from the databases; and the analysis and synthesis of the selected works, highlighting the results verified by each author.

\subsection{Search parameter definitions}

The search was carried out electronically on the Web of Science and Scopus databases, which are reference platforms for citations, accessed through the CAPES (Coordenação de Aperfeiçoamento de Pessoal de Nível Superior) journal portal.

In the base, the advanced search and the Boolean operator "AND" were used, in addition, as search criteria, the terms "Big Data" and "Agricul *" were first used, which were searched for in the title field of the articles. Other delimitations used were in relation to the language, timing and type of document in which English was selected, the last 4 years (2016 to 2019) and article, respectively. It is important to highlight that the term "Agricul*" was used to broaden the research, as it was possible to select articles with the terms "Agricultural" and "Agriculture".

The selection using the Web of Science and Scopus database resulted in 38 (thirty-eight) and 35 (thirty-five) articles, respectively. Removing articles in duplicates and those that did not fit the delimited theme, 47 (forty-seven) articles remained. The Chart 1 shows the number of articles found in each database per year, and the number of duplicate, excluded and inserted articles. 


\section{Chart 1}

Search protocol summary

\begin{tabular}{|c|c|c|c|c|c|}
\hline Year & $\begin{array}{l}\text { Web of } \\
\text { Science }\end{array}$ & Scopus & $\begin{array}{l}\text { Duplicate } \\
\text { Articles }\end{array}$ & $\begin{array}{l}\text { Excluded } \\
\text { Articles }\end{array}$ & $\begin{array}{l}\text { Inserted } \\
\text { Articles }\end{array}$ \\
\hline 2016 & 6 & 4 & 2 & 2 & 6 \\
\hline 2017 & 8 & 10 & 3 & 1 & 14 \\
\hline 2018 & 9 & 9 & 6 & 1 & 11 \\
\hline 2019 & 15 & 12 & 4 & 8 & 16 \\
\hline Total & 38 & 35 & 15 & 12 & 47 \\
\hline
\end{tabular}

Source: The authors (2020).

\subsection{Presentation and analysis of results}

Regarding the year of publication (Figure 1), it is noted that from 2016 to 2017 there was an evolution of publications ( 6 to 14 publications), in 2018 there was a decrease of 3 publications less than the previous year, and in 2019 the highest number was obtained publications, resulting in 16 articles.

Figure 1

Number of articles per year

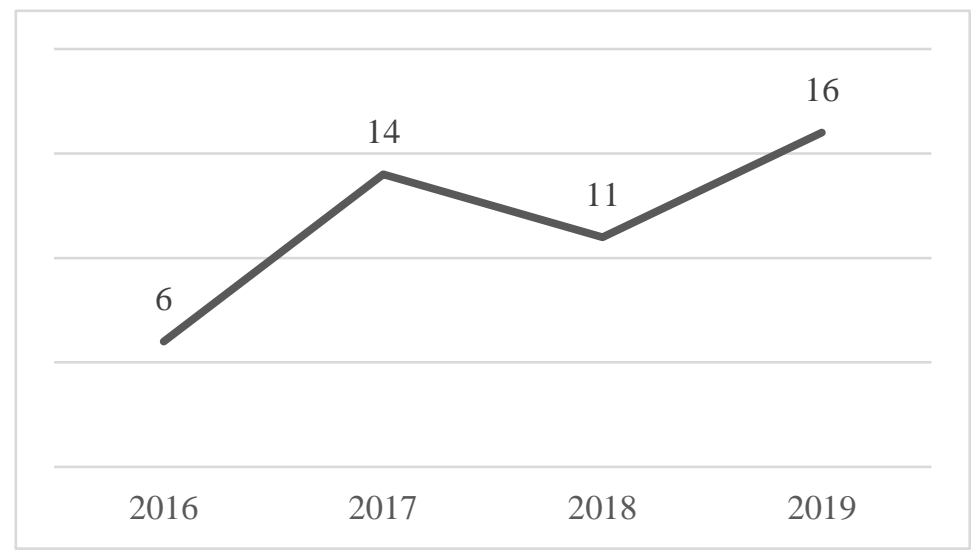

Source: authors (2020).

Regarding the title of the articles, a word cloud was created (Figure 2), using the software $R$ (2020). This cloud was formed by all 47 articles. In addition to the words referenced in the search, no other appeared with great prominence. The search terms were counted with the following frequency: "Data" appears 49 times, "big" 44, "agricultural" 21, "agriculture" 21. Other most cited terms were "analysis" 8, "analytics" 6 and "precision" 6, the other terms had frequency less than 5. 
Figure 2

Word cloud

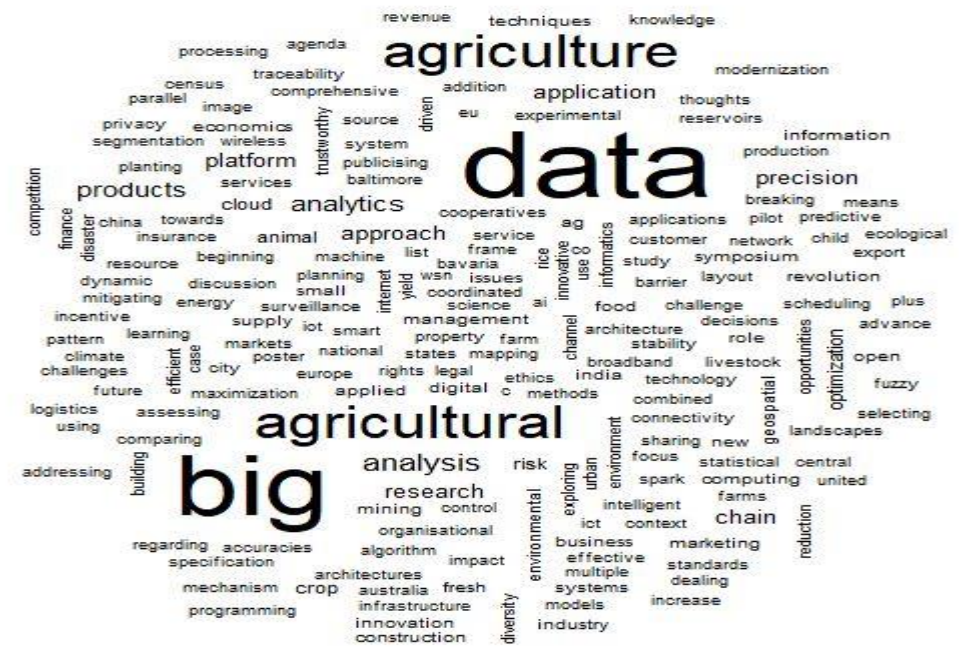

Source: authors (2020).

The 47 articles analyzed were published in 14 countries, with the United States the country that published the most articles on the topic (38\%) and secondly, England with 11\% of the articles published. The other countries, while participating in $51 \%$ of the publications, each published less than $10 \%$ of the total articles analyzed. The Figure 3 shows graphically the percentage of publications by country.

Figure 3

Number of articles published by country

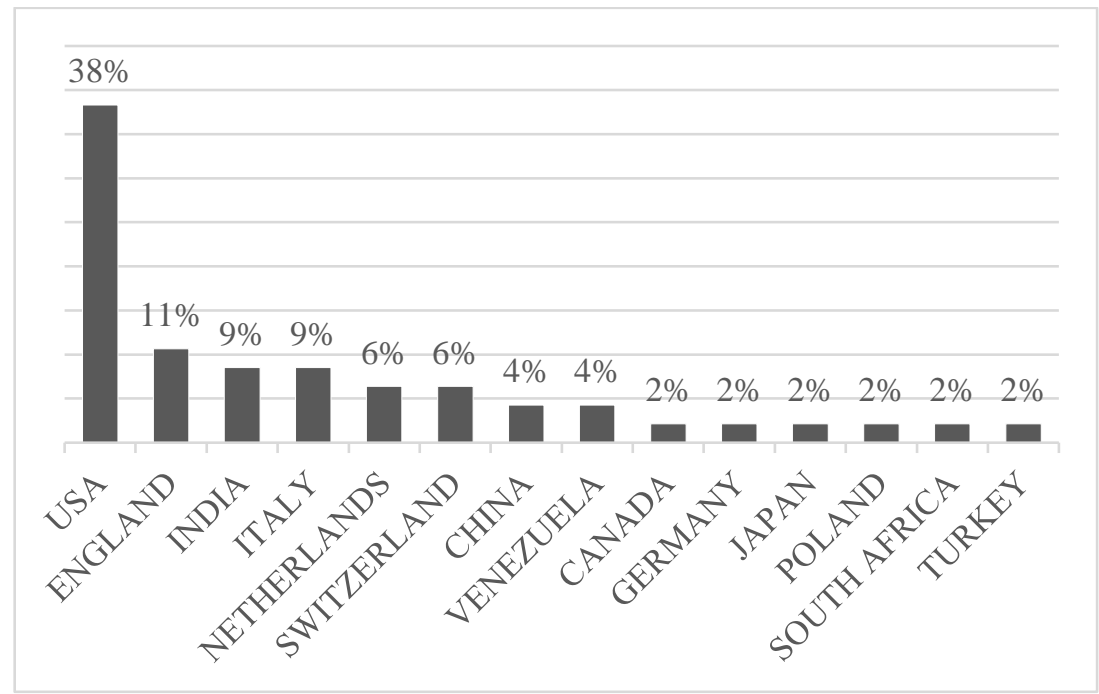

Source: Authors (2020) 
Figure 4 shows the keywords that appeared most frequently in all analyzed articles. These keywords can be associated with the methods most used in the context of Big Data in agriculture which are: Data Analysis, Machine Learning and Internet of Things.

Figure 4

Keywords

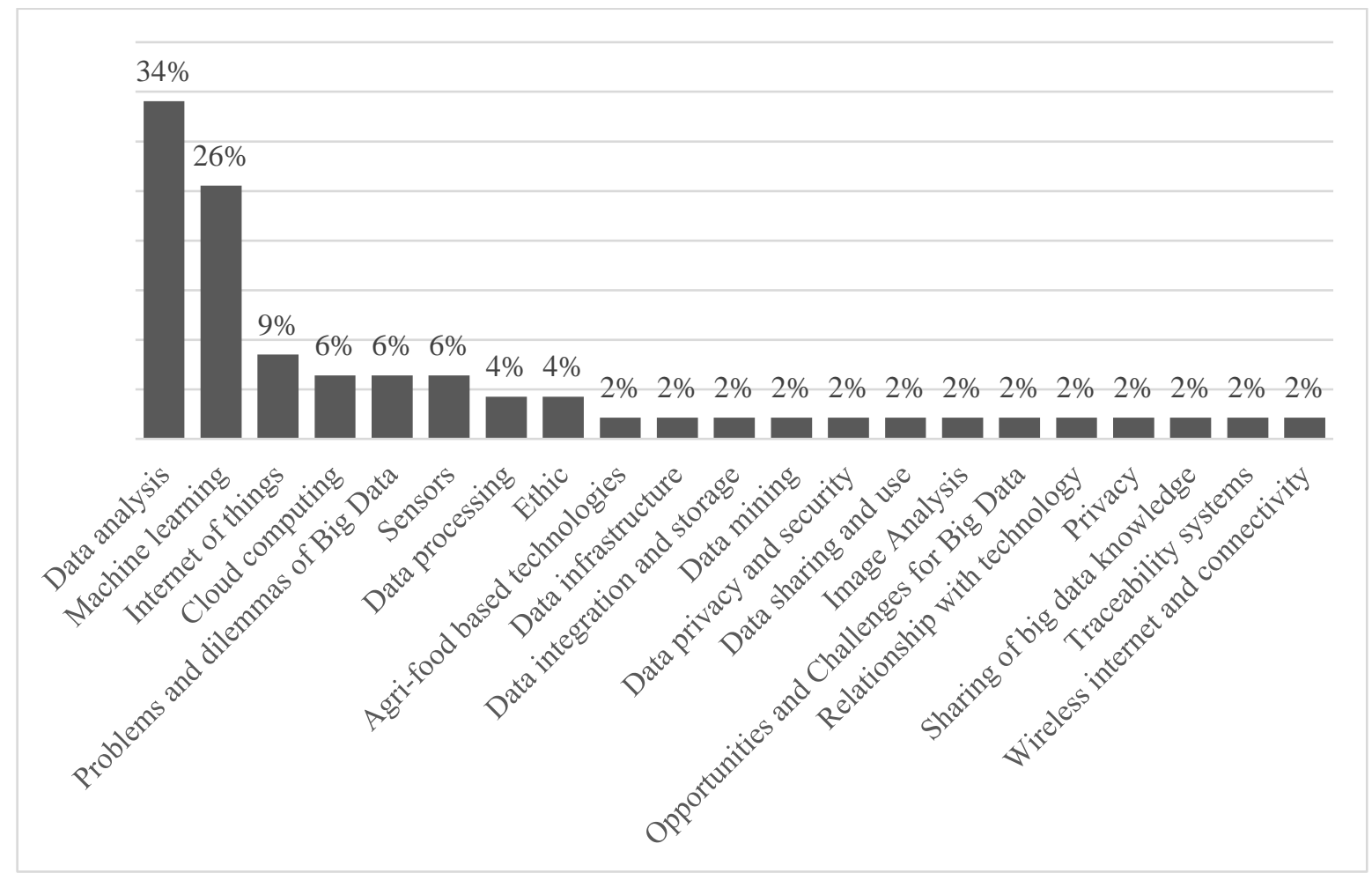

Source: Authors (2020)

\section{Results}

In order to identify how the application of Big Data analysis can enhance innovations for agriculture, the current scenario, the challenges to be overcome and perspectives for the sector, a synthesis of the 47 selected articles was made highlighting the main contributions of each study for the theme, as shown in Chart 2. 
Chart 2

Summary of the searched articles

Author

\begin{tabular}{|l|l|}
\hline Bhogireddy et al. (2016) & Use of Big Data to select the best performing rice genotypes. \\
\hline Ludena \& Ahrary (2016) & $\begin{array}{l}\text { It addresses the reasons that Big Data methodologies will be widely } \\
\text { used in analyzing agricultural data. }\end{array}$ \\
\hline Jia et al. (2017) & $\begin{array}{l}\text { Review of relevant concepts of agricultural Big Data, such as, main } \\
\text { applied technologies and, problems that agricultural Big Data has } \\
\text { been facing at the present stage and its application perspective. }\end{array}$ \\
\hline
\end{tabular}

Jones et al. (2017)

The article compares a range of water reservoir monitoring

Liu (2017)

Luo \& Liu (2017)

Priya \& Geetha (2017)

Shuo (2017)

Ravichandran

Kareemulla (2018)

\section{$\&$}

Contribution methods and establishes levels of precision in the characterization of these reservoirs.

It brings a combination analysis between internet + and Big Data, in order to assist in the trade of fresh agricultural products through e-commerce.

The study provides an analysis of e-commerce and marketing innovation in the use of fresh agricultural products. The study was based on Big Data from the internet, such as social networks.

Use of an algorithm based on dynamic programming to optimize the need for water, fertilizers and micronutrients based on availability and demand at each growth stage of a crop.

Use of Big Data to build China's ecological agriculture industrial chain.

Keywords/Applied methods

Data Analysis

Data Analysis

Data Analysis

Data Analysis; Image Analysis

Data Analysis

Data Analysis

Data Analysis; sensor

Data Analysis

Data Analysis collected from agricultural experiments.
Shivappa et al. (2018)

Review of Big Data, digital revolution, internet of things, and sensor technologies in the agricultural sector.

Data Analysis;
Internet of things;
Sensors;
Computing

Weigel et al. (2018)

The article shows that the composition of the crop portfolios is related to the socioeconomic characteristics of agricultural properties and restricted by the quality of the local soil and the size of the property. In addition, more diversified crop portfolios today do not promote greater revenue stability from the use of arable land in the study area, where policy still indirectly influences the market prices of energy crops.

Young et al. (2018)

The study brings a pilot project, applied in the city of Baltimore, with the purpose of trying to identify urban agricultural activities, through an analysis based on images and keywords made available on the web.

Lee et al. (2019)

Use of Big Data techniques to predict the risk of agricultural

Data Analysis 


\begin{tabular}{|c|c|c|}
\hline & drought in South Korea. & \\
\hline Li et al. (2019b) & $\begin{array}{l}\text { Development of a data analysis platform capable of identifying } \\
\text { causes of failure and maintenance requirements for agricultural } \\
\text { machinery. }\end{array}$ & Data Analysis \\
\hline Matsumoto et al. (2019) & $\begin{array}{l}\text { Development of a forecasting algorithm for the growth of } \\
\text { agricultural crops that considers seasonal changes. Data on crop } \\
\text { growth and climatic conditions are collected using sensors spread } \\
\text { across the field. }\end{array}$ & Data Analysis \\
\hline Zilberman (2019) & $\begin{array}{l}\text { It highlights the economic evolution in the context of agriculture } \\
\text { and brings an approach on the usefulness of Big Data to test } \\
\text { hypotheses, political approaches, among others. }\end{array}$ & Data Analysis \\
\hline Cameron et al. (2017) & $\begin{array}{l}\text { Use of the TRADE - Decision Support Model methodology to } \\
\text { identify export opportunities for agricultural products. }\end{array}$ & Machine Learning \\
\hline Carolan (2017) & $\begin{array}{l}\text { It is an analysis based on interviews with farmers, professionals } \\
\text { specializing in Big Data and entrepreneurs in the food sector. The } \\
\text { objective was to reformulate the discussion on technologies for the } \\
\text { agri-food industry. }\end{array}$ & Machine Learning \\
\hline Majumdar et al. (2017) & $\begin{array}{l}\text { It analyzes different data mining techniques for forecasting crop } \\
\text { yields, presents results on the analysis of the best climate to } \\
\text { achieve the highest wheat production. }\end{array}$ & Machine Learning \\
\hline Coble et al. (2018) & $\begin{array}{l}\text { This article examines the challenge and opportunities of Big Data } \\
\text { and concludes that these technologies will lead to relevant analysis } \\
\text { at all stages of the agricultural value chain. }\end{array}$ & Machine Learning \\
\hline Morota et al. (2018) & $\begin{array}{l}\text { It provides insight into machine learning and data mining in the } \\
\text { context of Big Data analysis with particular emphasis on } \\
\text { forecasting. }\end{array}$ & $\begin{array}{l}\text { Machine Learning; } \\
\text { Data Mining }\end{array}$ \\
\hline Tao et al. (2018) & $\begin{array}{l}\text { This article proposed a new approach to optimizing reliable supply } \\
\text { chain scheduling for agricultural products using Big Data. }\end{array}$ & Machine Learning \\
\hline White et al. (2018) & $\begin{array}{l}\text { Describes the process of using Big Data and the predictive } \\
\text { analytical framework to create tools that guide decisions in } \\
\text { production, health and animal welfare. It addresses the statistical } \\
\text { part and demonstrates methods for assessing the accuracy of } \\
\text { predictions. }\end{array}$ & Machine Learning \\
\hline Gumma et al. (2019) & $\begin{array}{l}\text { Development of a high spatial resolution product using Big Data } \\
\text { techniques and machine learning, with the aim of improving the } \\
\text { accuracy of the geographical position of individual farms in South } \\
\text { Asia. }\end{array}$ & Machine Learning \\
\hline Jiang et al. (2019) & $\begin{array}{l}\text { Development of a Big Data analysis model that aims to identify the } \\
\text { best place and the best time to cultivate each type of culture. }\end{array}$ & Machine Learning \\
\hline Ruan et al. (2019) & $\begin{array}{l}\text { The authors found that the proposed GA-SVM granular predictor is } \\
\text { effective for making big data predictions with reduced } \\
\text { computation time and equivalent precision. }\end{array}$ & Machine Learning \\
\hline
\end{tabular}


Author

Contribution
Keywords/Applied methods

Tantalaki et al. (2019) Literature review on Big Data applications for data-driven decision Machine Learning making in precision agriculture.

Tseng et al. (2019) Use of Internet of Things equipment to monitor the environmental factors of a farm and the data collected are subjected to 3D cluster Machine learning; analysis.

Zhang \& Liu (2019) Use of a model of neural networks that process meteorological data of agricultural lands.

Machine Leaning; Internet of things; sensors;

Li et al. (2019a) Proposal for an optimization method to filter redundant data Internet of things generated by Big Data techniques.

Gill et al. (2017)

A proposed cloud-based standalone system to provide Agricultureas-a-Service (AaaS). The system groups the information, from pre-

Cloud Comptuing; configured devices and IoT (Internet of Things), and processes in the cloud with Big Data applications.

Leone (2017)

Article addresses data ownership and privacy, misuse and the fear of large companies operating in the sector about data sharing.

Klauser (2018)

The study provides a review of "smart farming" and aims to analyze the creation, operation and performance of Big Data in the agricultural area.

Guo et al. (2019)

The text addresses the problems of application of Big Data in agriculture, such as weak infrastructure of agricultural information, weak awareness of data acquisition and saving, shortage of qualified professionals in Big Data, among others.

Liu et al. (2019)

Article covers agricultural image segmentation algorithms, as well as comparing the performance of Apache Spark technology.

Reznik et al. (2017)

He presented geospatial data processing approaches based on data from satellites and sensors that aim at the phases of prevention and mitigation of disaster risk reduction in agriculture.

Carbonell (2016)

It brings an analysis of the ethics of Big Data in the area of agriculture, focusing on the power that exists between farmers and large companies in the industry.

Ryan (2019) The text addresses that the use of Big Data analysis in agriculture can bring undesirable consequences, such as the exercise of power in the agricultural sector.

Yu et al. (2017)

Construction study of a large agricultural data infrastructure in China.

Woodard (2016) Provides an overview of the use of the Ag-Analytics platform, focusing on open data from available agricultural surveys.

Problems and dilemmas of Big Data

Problems and dilemmas of Big Data

Problems and dilemmas of Big Data

Data Processing

Data Processing

Ethic

Ethic

Data Infrastructure

Data integration and storage

Sykuta (2016) transition from precision farming to big data.

Data privacy and security 


\section{Author}

Contribution
Keywords/Applied methods

Chen \& Cheng (2018) The article provides an organizational structure and suggestions related to the preservation and use of Big Data, in order to provide references for sharing and using data for agricultural research in China.

Weersink et al. (2018) The study provides an analysis of the state of the art on the potential of Big Data to improve and reinvent agriculture.

Data sharing and use
Opportunities and Challenges for Big Data

Relationship with technology; Privacy

Sharing of big data knowledge Study of mechanisms to encourage knowledge sharing between producers and distributors, based on distinguishing customer knowledge differences in traditional scenarios and Big Data context.

Giagnocavo et al. (2017) It addresses the case of a cooperative and how it uses Big Data in traceability tools, and the benefit of small producers in the chain.

Mark, et al. (2016) The study deals with data transfer in precision agriculture and how to improve connectivity to spread Big Data in this area.
Traceability systems

Wireless internet and connectivity

Source: The authors (2020).

As shown in Chart 2 of the summary of the articles selected above, the use of Big Data promotes a huge set of possibilities in the field of agriculture, from increasing productivity to risk management. Shivappa et al. (2018) state that the agriculture sector currently has technology similar to the latest generation industrial sector, using GPS equipped with sensors, e-tablets and drones, in addition to also taking advantage of the power of the Internet of Things and Big Data in all its agricultural value chain.

Due to climatic seasonality, data analysis is the most used technique in agriculture to help in the optimization of scarce resources such as water, fertilizers and micronutrients (Priya \& Geetha, 2017), as well as in helping to select the best performing genotypes for cultivation (Bhogireddy et al., 2016).

In addition to the aforementioned, it is also noted that with the growth of the advent of Big Data, in which tools routinely monitor and collect information from animals and farms, several methods of analysis need to be used, to efficiently extract and summarize the main information, thus, machine learning and data mining methods have been widely used (Majumdar et al., 2017).

With regard to machine learning, which is the second most used method in agriculture in the context of Big Data and which is capable of making predictions from a set of data, its applications are diverse, such as facilitating production decisions livestock (White et al., 2018), improve accuracy in the geographical location of farms (Gumma et al., 2019) and identify the best place and the right time to cultivate a particular crop (Jiang et al., 2019). 
As Morota et al. (2018), machine learning can be combined with data mining for applications involving agriculture, such as genome prediction, identification of outliers of a certain group of animals and detection of mastitis (disease that affects the health of dairy cattle). The machine learning method is also used in equipment with Internet of Things technology and sensors, which monitor the environmental factors of a farm, such as soil temperature and humidity, in order to answer whether a crop is suitable for cultivation (Tseng et al., 2019).

According to Zhang \& Liu (2019), in agriculture, the loT assists in data collection, transmission and monitoring. Examples of this application are the use of sensors that capture environmental data in real time, being: images of the climate in the agricultural area. Therefore, the application of IoT in agriculture also supports the collection of meteorological data, such as: temperature, air humidity, light intensity, among others. This means that those responsible can be alerted to the weather, disasters and thus reduce the losses related to possible damage, since this technology has an effective response speed.

There are also initiatives to structure online tools that allow interested parties and decision makers to view and analyze data on agriculture, facilitating policy formulation.

On the other hand, according to Shivappa et al. (2018), there are some challenges to be overcome for the full exploitation of agriculture combined with Big Data, which are: digital literacy, internet access and its speed and lack of participation by companies and private industries.

\section{Conclusion}

Traditional software cannot process the amount of information and variables in data sets, Big Data, so it is necessary to search for ways to correctly mine this data, understand what is present on the internet and use it in favor of the business in the competitive market. Understanding the consumer's needs is necessary in any type of business, including agriculture, in addition, decision making cannot cause negative impacts on the process or on the final product. In addition, the collaboration of professionals in computer science, economics, engineering, mathematics and statistics is necessary, together with the industry, to efficiently develop approaches to analyze high volume of data.

Thus, the objective of this work was to carry out a systematic review of the literature regarding the current issues that address the use of Big Data in the context of agriculture. In total, 47 articles on the topic were published, published between 2016 and 2019, linked on the Web of Science and Scopus platforms.

From the research question "Currently, what are the innovations and technologies, linked to Big Data, used in agriculture?", The analyzes indicated that there is a relatively high approach on the subject in the last 4 years and brings great contributions, such as: the application of algorithms, combinations 
with internet + and cloud, statistical analysis, technologies that make up industry 4.0, in addition to presenting several applications in the subareas of agriculture.

Knowing all these technologies related to Big Data, which are used in agriculture in first world countries, serve as a reference for innovative practices for agricultural companies, who wish to improve their current production processes (AS-IS), through the application of technologies emerging, thus generating highly competitive future processes (TO-BE).

As a suggestion for future work, it is interesting to understand how is the Big Data approach in Brazil, focused on agriculture and perform a comparative analysis to identify existing technologies, as well as the projection of technological advent in the area.

\section{References}

Bhogirredy, S. et al. (2016). Dealing with Big Data in agriculture through management information system: A case of coordinated rice research. International Journal of Agricultural and Statistical Science. v. 12, p. 537 - 545.

Cameron, M.; Viviers, W.; Steenkamp, E. (2017). Breaking the 'Big Data' barrier when selecting agricultural export markets: an innovative approach. Agrekon. v. 56, p. 139 - 157, 2017.

Carbonell, I. (2016). The ethics of Big Data in big agriculture. Internet Policy Review, v. 5, n. 1.

Carolan, M. (2017). Publicising food: Big Data, precision agriculture, and co-experimental techniques of addition. Sociologia Ruralis, v. 57, n. 2, p. 135-154, 2017.

Chen, X. \& Cheng, C. M. (2018). Research on agricultural information science and technology innovation based on Big Data. Journal of advanced oxidation technologies, v. 21, n. 2.

Coble, K. H. et al. (2018). Big Data in Agriculture: A Challenge for the Future. Applied Economic Perspectives and Policy. v. 40, p. 79-96.

Franco, M. C. \& Domenech, M. B. (2014). Agro Big Data: el próximo desafío. Agrobarrow 55.

Giagnocavo, C. et al. (2017). Agricultural cooperatives and the role of organisational models in new intelligent traceability systems and Big Data analysis. International Journal of Agricultural and Biological Engineering, v. 10, n. 5, p. 115-125.

Gill, S. S.; Chana, I.; Buyya, R. (2017). IoT based agriculture as a cloud and Big Data service: the beginning of digital India. Journal of Organizational and End User Computing (JOEUC), v. 29, n. 4, p. 1-23.

Gumma, M. K. et al. (2019). Agricultural cropland extent and areas of South Asia derived using Landsat satellite 30-m time-series big-data using random forest machine learning algorithms on the Google Earth Engine cloud. Giscience \& Remote Sensing, v. 57, n. 3, p. 302-322.

Guo, T. B. \& Wang, Y. F. (2019). Big Data Application Issues in the Agricultural Modernization of China. Ekologi, v. 28, n. 107, p. 3677-3688. 
Instituto Brasileiro de Geografia e Estatística (2019). Censo Agropecuário 2017: Resultados definitivos. Rio de Janeiro.

Jayashankar, P. et al. (2019) Co-creation of value-in-use through big data technology- a B2B agricultural perspective. Journal of business \& industrial marketing, v. 35, n. 3, p. 508-523.

Jia, J. D.; Kang, B. H.; Zhang, L. (2017). Discussion on Big Data statistical analytics application in agriculture. International Agricultural Engineering Journal, v. 26, p. 246-256.

Jiang, Y. M. et al. (2019). Big data analysis applied in agricultural planting layout optimization. Applied engineering in agriculture, v. 35, n. 2, p. 147-162.

Jones, S. K.; et al. (2017). Big Data and multiple methods for mapping small reservoirs: comparing accuracies for applications in agricultural landscapes. Remote Sensing, v. 9, n. 12, p. 1307.

Khan, A. \& Turowski, K. (2016) A Perspective on Industry 4.0: From Challenges to Opportunities in Production Systems. Proceedings of the International Conference on Internet of Things and Big Data (IoTBD), p. 441-448.

Klauser, F. (2018). Surveillance Farm: Towards a Research Agenda on Big Data Agriculture. Surveillance \& Society, v. 16, n. 3, p. 370-378.

Lee, J. W. et al. (2019). The relationship among meteorological, agricultural, and in situ newsgenerated big data on droughts. Natural Hazards, v. 98, n. 2, p. 765-781.

Leone, L. (2017). Addressing Big Data in EU and US agriculture: a legal focus. European Food and Feed Law Review, v. 12, n. 6, p. 507-518.

Li, D.; Zheng, Y.; Zhao, W. (2019a). Fault Analysis System for Agricultural Machinery Based on Big Data. IEEE Access, v. 7, p. 99136-99151.

Li, J. B.; Li, X. H.; Peng, Y. B. (2019b). Application of Big Data in Agricultural Internet of Things. Revista de la facultad de agronomia de la universidad del zulia, v. 36, n. 5, p. 1521-1529.

Liu, B.; et al. (2019). A spark-based parallel fuzzy \$ c \$-Means segmentation algorithm for agricultural image Big Data. IEEE Access, v. 7, p. 42169-42180.

Liu, Y. (2017). Innovation of marketing pattern of fresh agricultural products based on internet plus and Big Data platform. Agro food industry hi-tech, v. 28, n. 3, p. 1739-1743.

Ludena, R. D. A. \& Ahrary, A. (2016). Big Data approach in an ICT agriculture application. In: New Approaches in Intelligent Control. Intelligent Systems Reference Library, v. 107, p. 109-134.

Luo, J. \& Liu, D. (2017). Fresh agricultural products e-business chain logistics and risk control based on Big Data platform. Boletin Tecnico/Technical Bulletin, v.55, n.6, p. 200-208.

Majumdar, J.; Naraseeyappa, S.; Ankalaki, S. (2017). Analysis of agriculture data using data mining techniques: application of Big Data. Journal of Bid Data, v. 4, n. 1.

Manyika, J. et al. (2013). Disruptive technologies: advances that will transform life, business, and the global economy. San Francisco, CA: McKinsey Global Institute. 
Mark, T. B. et al. (2016). The role of wireless broadband connectivity on 'Big Data' and the agricultural industry in the United States and Australia. International Food and Agribusiness Management Review, v. 19, n. 1030-2016-83150, p. 43-56.

Matsumoto, Y. et al. (2019). Modeling and simulation of agriculture production system considering seasonal variable information using big data analysis. Journal of advanced mechanical design systems and manufacturing, v. 13, n. 5.

Morota, G. et al. (2018). Big Data analytics and precision animal agriculture symposium: Machine learning and data mining advance predictive Big Data analysis in precision animal agriculture. Journal of Animal Science, v. 96, n. 4, p. 1540-1550.

Morais, I. S.; et al. (2018). Introdução a Big Data e Internet das Coisas (IOT). Porto Alegre: SAGAH.

Priya, N.; Geetha, G. (2017). Dynamic Programming Based Resource Optimization in Agricultural Big Data for Crop Yield Maximization. Journal of Computational and Theoretical Nanoscience, $v$. 14, p. 4464-4470.

R Core Team (2020). R: A language and environment for statistical computing. R Foundation for Statistical Computing, Vienna, Austria. URL https://www.R-project.org/.

Ravichandran, S. \& Kareemulla, K. (2018). Agricultural data analytics - Small to Big Data. International Journal of Agricultural and Statistical Sciences, v. 14, n. 1, p. 211-214.

Resnik, T. et al. (2017). Disaster Risk Reduction in Agriculture through Geospatial (Big) Data Processing. International Journal of Geo-Information, v.6, n. 8, p. 238.

Ribeiro, J. G.; Marinho, D. Y.; EspinosA, J. W. M. (2018). Agricultura 4.0: desafios à produção de alimentos e inovações tecnológicas. In: SIENPRO, 2018, Catalão - GO. II SIENPRO.

Ruan, J. H. et al. (2019) A Granular GA-SVM Predictor for Big Data in Agricultural Cyber-Physical Systems. IEEE transactions on industrial informatics, v. 15, n. 12, p. 6510-6521.

Ryan, M. (2019). Agricultural Big Data Analytics and the Ethics of Power. Journal of agricultural \& environmental ethics, v. 33, n. 1, p. 49-69.

Shen, N. (2019). Customer Knowledge Sharing Incentive Mechanism in Agricultural Products Supply Chain in Big Data Context. Revista de la Facultad de Agronomía. v. 36, p. $243-251$.

Shivappa, S.; et al. (2018). Digital revolution and Big Data: a new revolution in agriculture. $C A B$ Reviews: Perspectives in Agriculture, Veterinary Science, Nutrition and Natural Resources, v. 13.

Shuo, Q. (2017). Construction of the industry chain of ecological agriculture combined with Big Data. Agro Food Industry Hi Tech. v. 28.

Sykuta, M. E. (2016). Big Data in Agriculture: Property Rights, Privacy and Competition in Ag Data Services. International Food and Agribusiness Management Review, v. 19.

Tantalaki, N.; Souravlas, S.; Roumeliotis, M. (2019). Data-Driven Decision Making in Precision Agriculture: The Rise of Big Data in Agricultural Systems. Journal of agricultural \& food information, v. 20, n. 4, p. 344-380. 
Tao, Q. et al. (2018). Big Data driven agricultural products supply chain management: a trustworthy scheduling optimization approach. IEEE Access, v. 6, p. 49990-50002.

Tranfield, D.; Denyer, D.; Smart, P. (2003). Towards a methodology for developing evidence-informed management knowledge by means of systematic review. British journal of Management, v. 14, n. 3, p. 207-222.

Tseng, F. H.; Cho, H. H.; Wu, H. T. (2019). Applying Big Data for Intelligent Agriculture-Based Crop Selection Analysis. IEEE Access, v. 7, p. 116965-116974.

Weersink, A. et al. (2018). Opportunities and challenges for Big Data in agricultural and environmental analysis. Annual Review of Resource Economics, v. 10, p. 19-37.

Weigel, R.; Koellner, T.; Poppenborg, P.; Bogner, C. (2018). Crop diversity and stability of revenue on farms in Central Europe: An analysis of Big Data from a comprehensive agricultural census in Bavaria. PLOS ONE.

White, B. J.; Amrine, D. E.; Larson, R. L. (2018). Big Data analytics and precision animal agriculture symposium: Data to decisions. American Society of Animal Science, v. 96, n. 4, p. 1531-1539.

Woodard, J. (2016). Big Data and Ag-Analytics An open source, open data platform for agricultural \& environmental finance, insurance, and risk. Agricultural finance review, v. 76, n. 1, p. 15-26.

Young, L. J.; et al. (2018). Exploring a Big Data approach to building a list frame for urban agriculture: a pilot study in the city of Baltimore. Journal of Official Statistics, v. 34, n. 2, p. 323-340.

Yu, L. M.; et al. (2017). Construction and thoughts regarding national agricultural Big Data infrastructure. International Agricultural Engineering Journal, v. 26, p. 341-348.

Zhang, C. L.\& Lui, Z. F. (2019). Application of big data technology in agricultural Internet of Things. International journal of distributed sensor networks, v. 15, n. 10.

Zilberman, D. (2019). Agricultural economics as a poster child of applied economics: Big Data \& big issues. American Journal of Agricultural Economics, v. 101, n. 2, p. 353-364. 